\title{
Medicinal products market and financial position of pharmaceutical companies in the Republic of Croatia
}

Bajo, Anto; Čavić, Sanja; Primorac, Marko

Source / Izvornik: Fiscus: prudent and responsible public sector financial management, 2019, 4, 1 - 20

Journal article, Published version

Rad u časopisu, Objavljena verzija rada (izdavačev PDF)

https://doi.org/10.3326/efiscus.2019.8

Permanent link / Trajna poveznica: https://urn.nsk.hr/urn:nbn:hr:242:064530

Rights / Prava: Attribution-NonCommercial-NoDerivatives 4.0 International/Imenovanje-

Nekomercijalno-Bez prerada 4.0 međunarodna

Download date / Datum preuzimanja: 2023-04-26

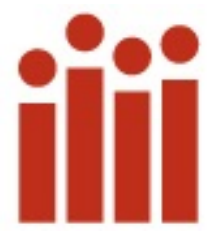

Repository / Repozitorij:

Institute of Public Finance Repository

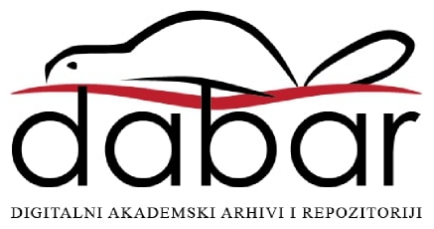


Institute of
Public Finance

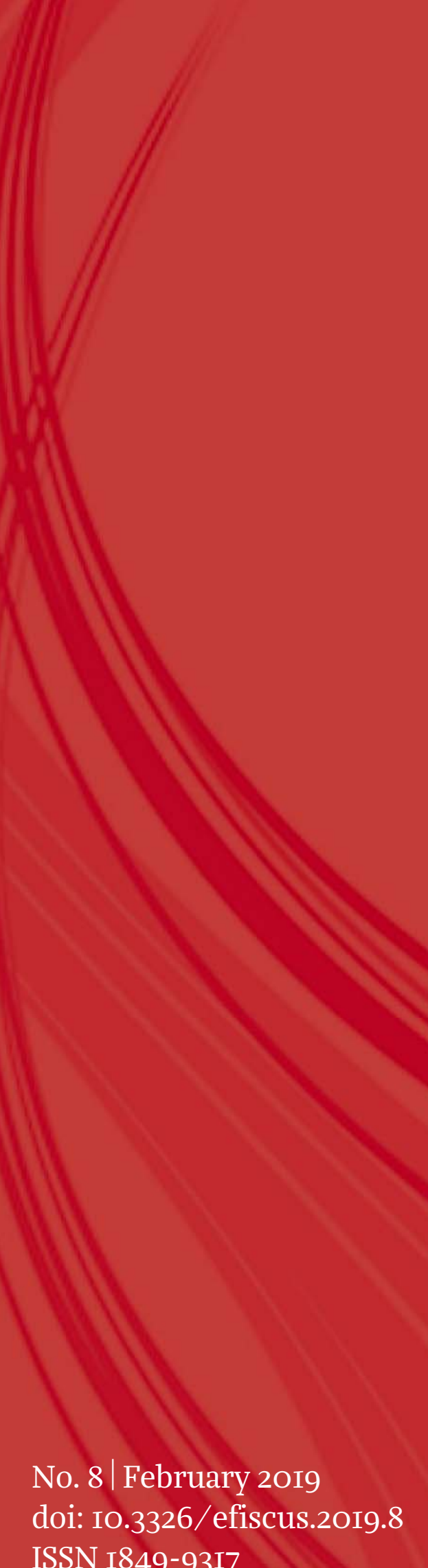

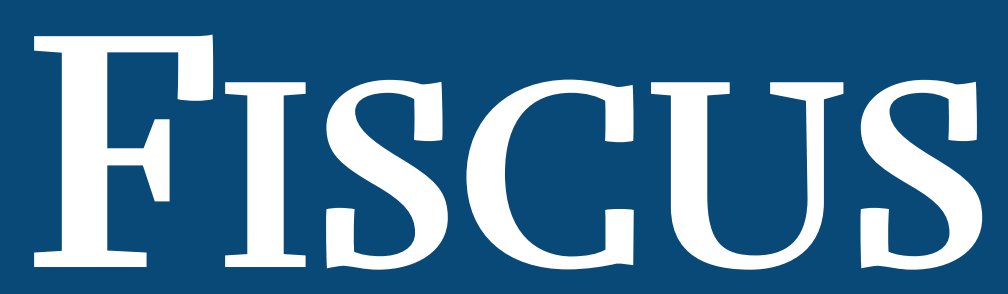

Prudent and responsible public sector financial management

\section{Medicinal}

products market and financial

position of

pharmaceutical

sompanies in

A terepublic of

Groth 

Anto Bajo

Sanja Čavić

Marko Primorac

Medicinal products

market and financial

position of pharmaceutical

companies in the

Republic of Croatia

The healthcare needs are unpredictable and inconsistent, and quite often their cost grows faster than the cost of living and real wages. The average life expectancy is set to increase by development and improvement of the standard of living, which automatically calls for higher expenses for financing of healthcare services. The continuous research and innovation in the segments of healthcare and pharmacy, as well as the increase in the number of expensive innovative medicinal products cause growth of prices of medicinal products sold by retail. The main aim of this paper is to analyse the pharmaceutical products market (level and structure of consumption) in Croatia and to assess the financial position of the main suppliers of medicinal products and the largest market participants pharmaceutical companies.

\section{Introduction}

The pharmaceutical industry - the manufacture of basic pharmaceutical products and pharmaceutical preparations - makes an important element of the processing industry. It is export-orientated (more than 60\%) and specific for its investments that contribute to the GDP growth (more than HRK 2 million of the added value) as well as research and development. The fluctuation in the pharmaceutical industry is largely influenced by demographic trends and economic conditions that affect the manufacture and profitability, as well as the development potential of the medicinal products market. The consumption of medicinal products is an important part of the healthcare spending, and the healthcare enjoys the status of the public good (interest); therefore, the medicinal products market is quite regulated, especially in the context of entry of a medicinal product on the market and pricing.

The pharmaceutical industry is often perceived as a cost generator. The gradual increase of life expectancy of the population and the increase in standard of living affect the increase in 
demand of pharmaceutical products. The life cycle of medicinal products as the main pharmaceutical products is very complex. The pharmaceutical industry continuously involves a large number of supporting industries, starting from the fundamental (preclinical) and clinical research, over the production and product management after patent expiry. Although facing many challenges - like overcapacity (excessive capacity for production in relation to demand), lack of new products and customers' requests for price reduction (Enright and Dalton, 2013), the pharmaceutical industry became a growth, export and investment driver as well as a driver of investments into research and development.

This paper analyses the scope and the structure of the Croatian medicinal products market, describes the main participants and assesses their financial position. Following the introduction, the second part analyses the scope of the medicinal products market in Croatia the institutional framework and the major market participants, especially the distribution of medicinal products in the period from 2010 to 2017 and their consumption. The third part assesses the financial position of ten largest pharmaceutical companies in Croatia in the period from 2013 to 2017 based on the consolidated balance sheets and income statements. It also includes the calculation and analysis of the selected financial performance indicators that are prepared for the assessment of the market position of the major participants. The fourth part comprises the conclusions.

\section{Medicinal Products Market in Croatia}

The consumption of medicinal products affects the costs of every modern healthcare system. The result of the increased economic prosperity is the increasing demand of patients for modern medicinal products and increasingly aggressive marketing used by the medicinal product manufacturers. Furthermore, as the medicine progresses, the patients' expectations are becoming higher, and thus the expenditure on medicinal products often grows much faster than the GDP growth rate, which impacts the financial sustainability of the healthcare system (Vehovec, 20I4). There are particularities that make the medicinal products market different from other market and they include the government policy and legal factors, a high product impact, demanding technology and a long period required for development of a new products, fragmented market and a specific process of purchase.

The medicinal products market is one of the most heavily controlled and legally regulated markets, which refers to the medicinal product research, manufacture, registration i.e. marketing authorisation as well as distribution, sale and marketing. Specific restrictions and requirements vary somewhat from country to country. An especially important aspect in marketing of medicinal products is the ethical code that provides clear instructions on what is permitted and what is strictly prohibited. The pricing of medicinal products is also a special process controlled by the government.

One of the distinctive features of the medicinal products market is the demanding technology and a long-term process of development of new products. Research and development of medicinal products is a risky venture for every medicinal product manufacturer. About $20 \%$ of the total company revenue is invested in research of new molecules, and it is known that only around two hundred molecules out of every Io,ooo will successfully pass the testing, and hardly twenty of them will successfully pass the clinical testing to become a marketable medicine. Due to the large cost of their development, the innovative medicinal products have patent rights that 
grant the protection of intellectual property over the product for 20 years. In reality, this period is much shorter, since a medicinal product, before becoming marketable, must be subjected to numerous tests. The time required for the first copies of innovative medicinal products (generic medicinal products) to be placed on the market is ten to fifteen years, and this period is sometimes even shorter (DiMasi, 2015).

The availability of medicinal products on the market depends on collaboration between multiple interested parties - pharmaceutical industry, wholesalers, pharmacies, hospital systems, procurement policies referring to medicinals, patients (insured persons within healthcare protection system) and parliament, that makes decisions on the medicinal product policy (Ostojić et al., 2015).

Except acting in accordance with the provisions of the national legislations, the participants on the Croatian medicinal products market act also in accordance with regulations and guidelines that are applicable to all EU member countries. The Croatian medicinal products market is regulated by the Medicinal Products Act (Official Gazette, no. 76/13) pursuant to which the following ordinances were adopted: Ordinance on Benchmarks for the Pricing in Wholesale Distribution of Medicinal Products and Method of Reporting on Wholesale Prices (Official Gazette, no. 83/I3) and Ordinance on Benchmarks for Including Medicinal Products in the Basic and Supplementary List of Medicinal Products of the Croatian Health Insurance Fund (Official Gazette, no. 83/I3). The Medicinal Products Act sets out the procedure for testing and placing the medicinal products on the market, labelling, classification, distribution, pharmacovigilance and quality control of the medicinal products, advertising, supply of the Croatian market with medicinal products, supervision of medicinal products, tested medicinal products as well as active substances and excipients.

Pursuant to the Medicinal Products and Medical Devices Act (Official Gazette, no. 12I/O3), the Agency for Medicinal Products and Medical Devices of Croatia (HALMED) as the competent agency for market regulation was established in 2003. The Medicinal Products Act sets forth that it is permitted to place on the market only those medicinal products that obtained the approval of HALMED or European Commission and the medicinal products with the approval for parallel import or distribution. Any legal and natural entity and governmental body that comes into possession of medicinal products in any way is obliged to ensure their transport, storage and keeping in accordance with the conditions provided for by law. For the purpose of regulation of aforementioned provisions, the Ordinance on Good Practice in Wholesale Distribution of Medicinal Products - that regulates the right of distribution of the medicinal products - was adopted (Broz, 20I4).

The pharmaceutical inspection of the Ministry of Health of the Republic of Croatia is competent for the supervision related to tested medicinal products, active substances and excipients, and especially the supervision related to testing, manufacturing, distribution, brokering, quality control and advertising of medicinal products. The HALMED inspection supervises the manufacture of medicinal products, tested medicinal products, active substances and excipients as well as pharmacovigilance. ${ }^{\mathrm{I}}$

\footnotetext{
${ }^{\text {I }}$ Pharmacovigilance is a set of activities related to identification, assessment, understanding, prevention and procedure in case of adverse reactions, as well as new information about the medicinal product safety.
} 
The medicinal products policy in EU is established for each member country individually, but there are certain elements, such as the authorisation of the product for placement on the market, that are defined on the EU level. In the latest amendment of the Medicinal Products Act of 2013, the Croatian Parliament transposed in the Croatian legal system fifteen directives and Io regulations of the European Parliament, Council of Europe and European Commission. By the adoption of this amendment, the Croatian legal system has become fully harmonised with the EU legal system.

\section{Pharmaceutical Pricing Policy}

In the past ten years, the Ministry of Health of the Republic of Croatia improved the national pricing system of medicinal products and fees and made it comparable to the system applicable in EU. The Ordinance on Benchmarks for Pricing of Wholesale Distribution of Medicinal Products lays down the criteria - benchmark wholesale price of a medicinal product in other countries, level of the benchmark wholesale price and pharmacoeconomic study ${ }^{2}$.

The external evaluation model based on the benchmark prices of medicinal products in Croatia has been implemented since 200I. Since then the Ordinance on Benchmarks for the Pricing in Wholesale Distribution of Medicinal Products and Method of Reporting (Official Gazette, no. 84/OI, I29/O2, 87/O6, 9I/O6, I55/O9, 83/20I2, 83/2013) has been changed several times. The administrative measure of exemption of more than a half of the insured from the obligation of paying a percentage surcharge for the medicinal products adopted in 2002 caused a cost increase. Two years later, the medicinal product pricing policy was amended, and for the first time, there was a difference in prices between innovative and generic medicinal products. The 2006 amendment, introduced reference prices per therapeutic group in the calculation of the cost reimbursement for the prescription medicinal products. The internal reference system also defines the consumption of $4 \mathrm{I}$ therapeutic groups of the prescription medicinal products.

The Ordinance amendment from 2009, solved the issues of implementation of the provisions regarding the pricing and reimbursement that incurred as a consequence of removing the medicinal products of the first group from the list of especially expensive medicinal products, and thus the consumption of a larger number of the expensive medicinal products of the second and third group, which made the financial burden of the healthcare system even heavier. By means of the new 2012 Ordinance, the wholesale distribution price of a medicinal product (of the identical generic entity and identical dosage form) in Italy, Slovenia and Czech Republic or Spain and France became the basis for the reference wholesale price of that medicinal product.

The reference wholesale price of medicinal products is calculated for each medicinal product separately. If on the markets of the reference countries there are several essentially similar forms of a medicinal product manufactured by several different manufacturers, the average price of such medicine in the relevant country is used for the calculation. The reference price shall be set separately for patented original medicinal products, non-patented medicinal products and for generic medicinal products. The prices of all the above-specified groups of medicinal products may not be higher than the average reference price, and if that is the case, such prices need to be reduced to the average reference price. The reference price is the highest

\footnotetext{
${ }^{2}$ Pharmacoeconomic analysis - the economic analysis of the assessment of justification for the use of medicinal products in medical practice (application of the cost and benefit analysis and application of the economic indicators that are used in economic assessment of the treatment).
} 
price of a medicinal product that a marketing authorisation holder may charge for a medicinal product on the supplementary list of medicinal products (the price paid by the Croatian Health Insurance Fund plus the price paid by the insured person), whereas the medicinal products from the basic list of medicinal products and a part of medicinal products from the supplementary list (paid by the Croatian Health Insurance Fund) shall be regulated by additional regulations. Table I presents the calculation of the price of a medicinal product in accordance with the Ordinance (Broz, 20I4).

As a rule, the generic medicinal products are cheaper than the original medicinal products. The price of the first generic medicinal product may not be higher than $70 \%$ of the price of the original product from the medicinal product list of the Croatian Health Insurance Fund, and the price of a new (second) generic medicinal product may not be higher than 90\% of the price of the first generic medicinal product. The price of the third generic medicinal product and every one thereafter that is placed on the Croatian market may reach 90\% of the price of the new, i.e. the second generic medicinal product. Although the Ordinance provides the possibility of setting the price of the fourth medicinal product and every one thereafter to 90\% of the price of the second generic medicinal product, in reality, it happens that the marketing authorisation holders suggest prices of the new generic medicinal products that amount to $90 \%$ of the previous generic medicinal products, which positively affects the budget of the Croatian Health Insurance Fund (Broz, 20I4).

The Ordinance from 2013 introduced separate pricing for biologic generic medicinal products ${ }^{3}$ and enabled relatively cost-effective price conditions compared to other generic medicinal products. The price of the biologic generic medicinal product must not exceed $85 \%$ of the price of the original medicinal product from the list of the Croatian Health Insurance Fund, whereas the price of the new (second) biologic generic medicinal product may amount to $90 \%$ of the price of the first biologic generic medicinal product. In order for a medicinal product to be included in either the basic or the supplementary medicinal products list of the Croatian Health Insurance Fund, besides determining the price, a proposal for including the medicinal product in the list needs to be submitted. The requirement for the inclusion of the original medicinal products in the medicinal products list of the Croatian Health Insurance Fund or for the expansion of the indications for use, is submitting of an impact study of the medical product consumption to the budget of the Croatian Health Insurance Fund. Legal persons with a wholesale distribution authorisation - mostly wholesale pharmacies - are obligated to sell to the Croatian Health Insurance Fund the medicinal products from the basic and supplementary products list at specified prices. The wholesale pharmacies purchase medicinal products directly from the manufacturers in the country or import them from the foreign manufacturers. The wholesale price of a medical product (net of VAT) includes the manufacturer price (laid down by the Ordinance) ${ }^{4}$ increased by the customs fees (in the case of an imported medicinal product). The cost of the retail pharmacist service amounts to on average HRK 6.9 per single medicinal product i.e. prescription. The domestic medicinal product manufacturers may distribute their products either independently or through wholesale pharmacies. However, the wholesale margin and other dependant costs may not be higher than 8.5\% (Broz, 20I4)

\footnotetext{
${ }^{3}$ Biologic medicinal products are large, complex molecules produced by living organisms.

4 The price already includes the wholesale margin and relevant costs amounting to $8.5 \%$.
} 


\begin{tabular}{|c|c|}
\hline Medicinal product type & $\begin{array}{r}\text { Portion of the price paid by } \\
\text { the Croatian Health } \\
\text { Insurance Fund }\end{array}$ \\
\hline $\begin{array}{l}\text { The wholesale distribution price of a medicinal } \\
\text { product that comprises a completely new active } \\
\text { substance that substantially increases the } \\
\text { possibility of successful treatment and } \\
\text { recovery, and is placed on the Croatian market } \\
\text { for the first time }\end{array}$ & IOO\% of the reference price \\
\hline $\begin{array}{r}\text { The wholesale distribution price of a medicinal } \\
\text { product that is subject to a prescription and } \\
\text { that contains a completely new active } \\
\text { substance, and the supplementary list of } \\
\text { medical products of the Croatian Health } \\
\text { Insurance Fund comprises comparable } \\
\text { medicinal products with the same or similar } \\
\text { pharmacological and therapeutic features. }\end{array}$ & $\begin{array}{l}90 \% \text { of the price of the } \\
\text { cheapest comparable } \\
\text { medicinal product that is } \\
\text { included in the medicinal } \\
\text { products list of the Croatian } \\
\text { Health Insurance Fund }\end{array}$ \\
\hline \multirow[t]{2}{*}{$\begin{array}{l}\text { The wholesale distribution price of a medicinal } \\
\text { product that is not subject to a prescription, but } \\
\text { is prescribed in hospital, and that contains a } \\
\text { completely new active substance, and the } \\
\text { supplementary list of medical products of the } \\
\text { Croatian Health Insurance Fund comprises } \\
\text { comparable medicinal products with the same } \\
\text { or similar pharmacological and therapeutic } \\
\text { features. }\end{array}$} & IOO\% of the reference price \\
\hline & $\begin{array}{r}70 \% \text { of the price of the } \\
\text { original medicinal product } \\
\text { from the medicinal products } \\
\text { list of the Croatian Health } \\
\text { Insurance Fund }\end{array}$ \\
\hline $\begin{array}{r}\text { The price of the new generic } \\
\text { medicinal product }\end{array}$ & $\begin{array}{l}\text { 90\% of the price of the first } \\
\text { generic medicinal product } \\
\text { (or } 63 \% \text { of the price of the } \\
\text { original medicinal product } \\
\text { from the medicinal products } \\
\text { list of the Croatian Health } \\
\text { Insurance Fund) }\end{array}$ \\
\hline $\begin{array}{r}\text { The price of every new generic } \\
\text { medicinal product }\end{array}$ & $\begin{array}{r}90 \% \text { of the price of the new } \\
\text { (second) generic medicinal } \\
\text { product ( } 56.7 \% \text { of the price of } \\
\text { the original medicinal } \\
\text { product from the medicinal } \\
\text { products list of the Croatian } \\
\text { Health Insurance Fund) }\end{array}$ \\
\hline $\begin{array}{r}\text { The price of the biologic generic } \\
\text { medicinal product }\end{array}$ & $\begin{array}{r}85 \% \text { of the price of the } \\
\text { original medicinal product } \\
\text { from the medicinal products } \\
\text { list of the Croatian Health } \\
\text { Insurance Fund }\end{array}$ \\
\hline
\end{tabular}


In Croatia, HALMED has been tracking the consumption of medical products systematically and comprehensively only since 2004, and once a year it submits a report on the consumption to the Minster of Health, in accordance with the information obtained from legal and natural persons in wholesale and retail medicinal product distribution. The reports on the medicinal product consumption of European countries are mostly based on the information obtained from wholesale pharmacies, but the HALMED's report is based on the data on the medicinal product distribution obtained from all pharmacies (including hospital pharmacies), as well as on the data obtained from specialised retail stores for medicinal products. Such an approach grants a realistic overview of the medicinal product consumption since the data are based on the actual number of medicinal products issued to end users. The medicinal product consumption shows a growing trend in the period from 2010 to 2017 (see chart I). With an aim of reducing costs, the Croatian Health Insurance Fund introduced a new pricing system for medicinal products in 2012 - securing more generic medicinal products, which meant the reduction of prices of medicinal products as well as of the financial burden of the government budget. The implementation of these regulations in 2014 resulted in the increased distribution of certain groups of medicinal products, and the growth of overall cost was equally distributed over all groups of medicinal products (HALMED, 2OI8).

\section{Chart I Total spending on medicinal products and GDP in Groatia from 2010 to 2017 (HRK million)}

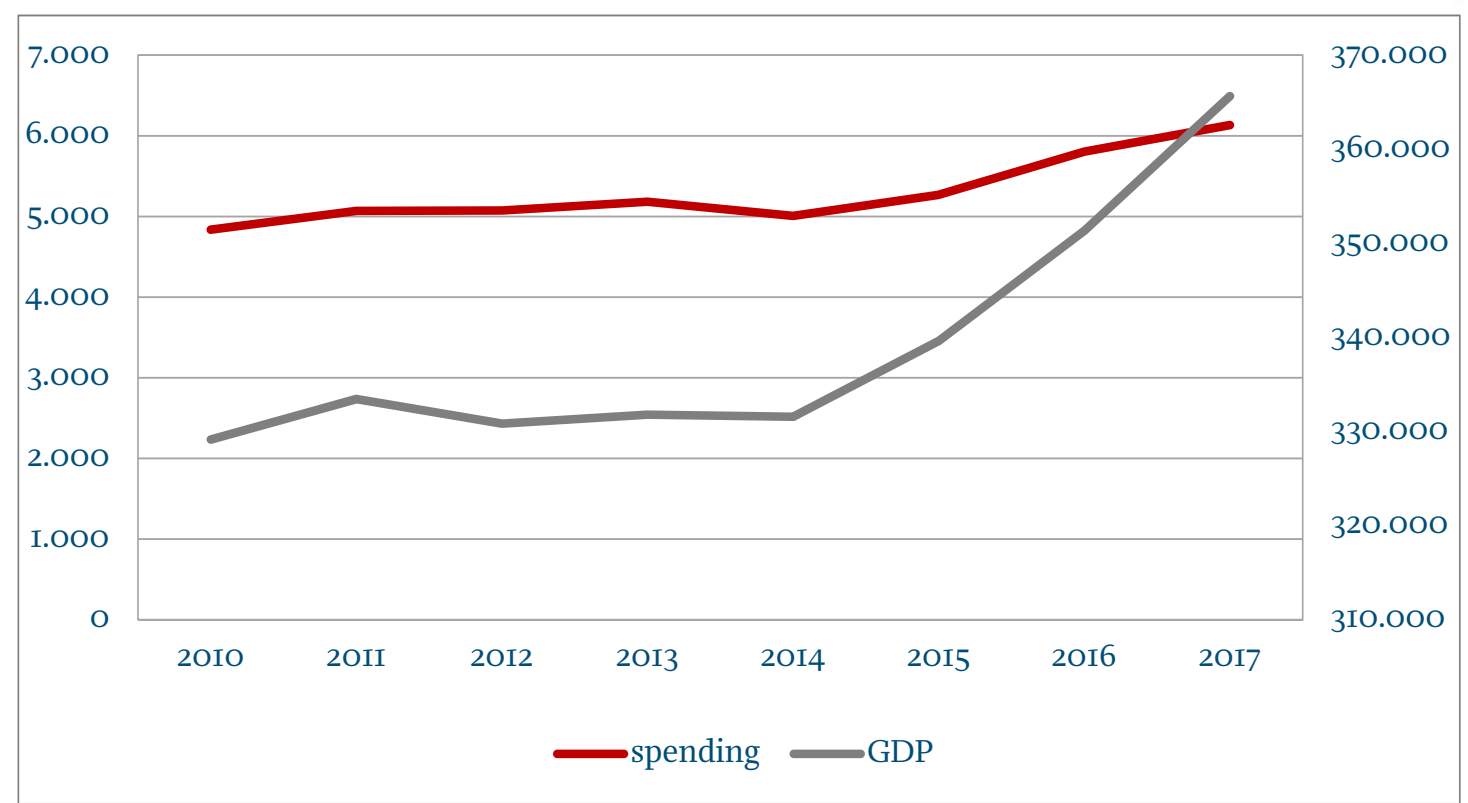

Source:

Agency for Medicinal Products and Medical Devices of Croatia (2018)

The spending on medicinal products had a growing trend, and in 2017 it amounted to HRK 6 billion. The substantial growth in spending on medicinal products by HRK I billion from 2014 to 2017 is related to the GDP growth.

Let us take a look at the consumption of medicinal products measured in number of defined daily doses / I,Ooo inhabitants per day, which amounted to I,045.88 DDD/I,Ooo inhabitants per day in 20I6. This means, that almost every inhabitant of the Republic of Croatia used one dose of medicine per day (see chart 2). The medicinal product consumption showed a growing 
trend expressed in DDD/I,Ooo inhabitants in the period from 2012 to 20I8. In 20IO, there were certain changes in DDD in specific ATC (Anatomical Therapeutic Chemical) groups, which resulted in reduced total results. The reason for this reduction is the change of DDD measurement units for specific medicinal products. E.g. DDDs for Cro group of medicinal products doubled, and therefore the final results halved. It is evident that the consumption of medicinal products per inhabitant has an upward trend - the average spending on medicinal products of every inhabitant in Croatia amounts to HRK I,257 per year, and a thousand of inhabitants spend a defined daily dose of a medicinal product every day.

\section{Chart 2 Total consumption of medicinal products per inhabitant expressed in HRK and in defined daily doses per I,ooo inhabitants per day in Croatia from 2013 to 2017}

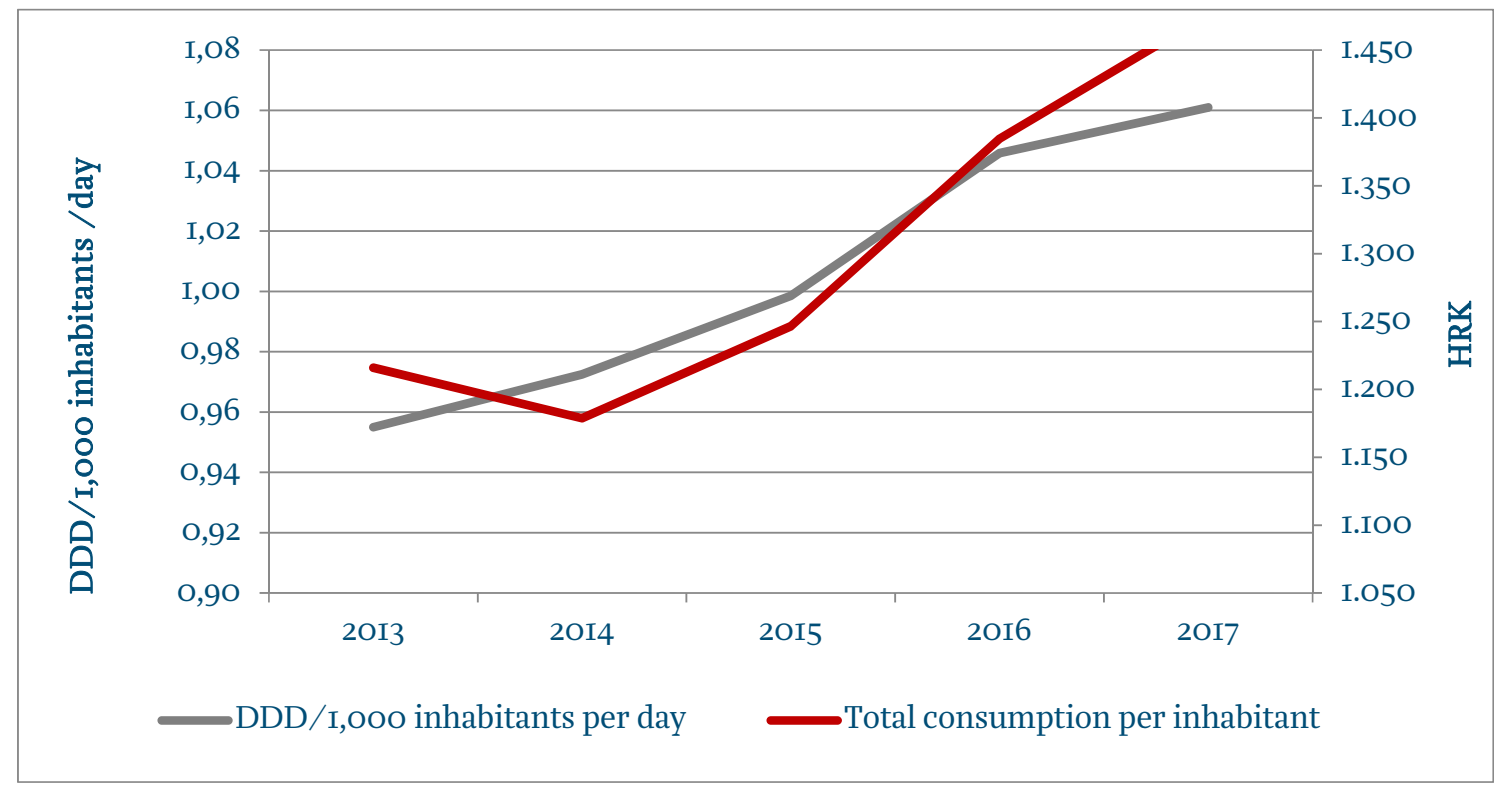

Source:

Agency for

Medicinal

Products and

Medical Devices

of Croatia (2018)

and Eurostat (2018)

One of the challenges that the Croatian pharmaceutical industry will be facing in the future is the strategic positioning - in terms of geographic positioning, as well as in terms of the product portfolio. The Croatian pharmaceutical industry is mostly focused on the manufacture of generic medicinal products that lose their market position because their revenue drops despite growing sale due to the price reduction. The generic medicinal products made $42 \%$ of the total revenue of the Croatian pharmaceutical industry in 2015 (Barbić, 20I7).

It is evident that the companies on the Croatian market must keep up with the developments on the global medicinal products markets since emerging markets have recorded increased demand of medicinal products and services as a result of demographic changes and easier access to healthcare.

The structure of medicinal product consumption in 2016 (chart 3) shows that the medicinal products for treatment of malignant diseased and immunomodulators made 2I\% of the total sales volume of medicinal products (the original medicinal products in the group of expensive medicinal products are also included). Such medicinal products have a great significance since in the past couple of years we have experienced the increased occurrence of malignant diseases. The group C medicinal products (affecting the cardiovascular system) made $13 \%$ of the consumption. Prices of medical products of this group gradually decrease every year. 
Total spending on medicinal products and sales revenue

In the considered period, the medicinal product consumption grew, but the revenue of pharmaceutical manufacturers grew even more being on average HRK I.5 billion higher than the total spending. This shows that the pharmaceutical industry is a very lucrative and profitable business.

Table 2 Total spending on medicinal products and total sales revenue of ten pharmaceutical companies in Croatia from 2013 to 2017 (HRK million)

\begin{tabular}{|c|c|c|c|c|}
\hline Year & $\begin{array}{r}\text { Sales } \\
\text { revenue }(\mathbf{I}) \\
\end{array}$ & $\begin{array}{r}\text { Total } \\
\text { spending (2) } \\
\end{array}$ & $\begin{array}{r}\text { Difference } \\
(\mathbf{I}-2) \\
\end{array}$ & \multirow{7}{*}{$\begin{array}{l}\text { Source: } \\
\text { Agency for Medicinal } \\
\text { Products and Medical } \\
\text { Devices of Croatia } \\
\text { (2OI8) and Financial } \\
\text { Agency }\end{array}$} \\
\hline 2013 & 6,369 & 5,183 & I,I86 & \\
\hline 2014 & 6,668 & 5,006 & I,662 & \\
\hline 2015 & $7, \mathrm{OIO}$ & 5,267 & $\mathrm{I}, 743$ & \\
\hline 2016 & 7,671 & 5,803 & $\mathrm{I}, 868$ & \\
\hline 2017 & 8,007 & 6,132 & $\mathrm{I}, 875$ & \\
\hline $2013-2017$ & 35,725 & 27,391 & 8,334 & \\
\hline
\end{tabular}

In the considered four years, the total spending on medicinal products amounted to HRK 27.4 billion, and the revenue of pharmaceutical companies generated by selling medicinal products amounted to HRK 35.7 billion.

Outstanding government liabilities of government owned healthcare institutions

The demand of healthcare institutions (mostly hospitals) and their inability to settle their debt to suppliers (wholesale pharmacies and pharmaceutical companies) has a substantial impact on 
the medicinal products market. The annual cost of outstanding invoices for medicinal products rarely amounts to less than HRK 0.5 billion.

Table 3 Scope and structure of outstanding liabilities of healthcare institutions 2012 to 2018 (HRK million)

\begin{tabular}{|c|c|c|c|c|c|c|}
\hline & 2013 & 2014 & 2015 & 2016 & 2017 & \multirow{10}{*}{$\begin{array}{l}\text { Source: } \\
\text { Croatian Health } \\
\text { Insurance Fund, } \\
\text { annual business } \\
\text { reports from } \\
2 \mathrm{OI} 2 \text { to } 2017\end{array}$} \\
\hline $\begin{array}{r}\text { Compulsory health } \\
\text { care insurance }\end{array}$ & I,39I.3 & 933.2 & 487.9 & 866.6 & 475.0 & \\
\hline Medicinal products & I,295.I & 774.3 & 458.9 & 851.9 & 448.5 & \\
\hline $\begin{array}{r}\text { Supplementary health } \\
\text { care insurance }\end{array}$ & I. 2 & I.O & 7.I & 2.3 & I.6 & \\
\hline Allowances & 36.0 & 5.3 & 2.6 & 6.6 & 5.6 & \\
\hline Specialist service & 0.6 & 0.6 & $2 . I$ & O.I & 0.2 & \\
\hline Capex & 0.7 & 0.0 & 0.0 & 0.0 & O.O & \\
\hline $\begin{array}{l}\text { Mutual liabilities } \\
\text { of budgetary units }\end{array}$ & 184.3 & I58.0 & - & - & - & \\
\hline Total & $\mathrm{I}, 6 \mathrm{I} 4.2$ & I,O98.I & 499.7 & 875.5 & 482.4 & \\
\hline $\begin{array}{r}\text { Medical products } \\
\text { as a percentage of the overall } \\
\text { outstanding liabilities }\end{array}$ & 80.2 & 70.5 & 91.8 & $97 \cdot 3$ & 93.0 & \\
\hline
\end{tabular}

Due to constant exceeding of the time-limit, the liabilities owed to suppliers are mostly settled by the Government and the Ministry of Finance, which use borrowing (on the domestic and foreign financial market) for a lump sum reduction of the hospitals' liabilities for medicinal products when the value of outstanding liabilities exceeds HRK I billion. As a consequence of borrowing, the liabilities are partially bailed-in, and then they gradually accumulate within a two to three-year period and again reach the value of above HRK I billion. Despite longer collection periods, the participants on the medicinal products market are patient because they will manage to collect their claims even if the time-limits are exceeded, and they will also charge the penalties for late payment. On the other hand, the public health institutions are the main client worth doing business with and worth waiting for, because the collection of claims is guaranteed. At the same time, these institutions cause the late payment due to irresponsible actions, bad planning and management of the medicinal products. The Croatian Health Insurance Fund acts as if they do not care, because the government is the party that eventually settles all liabilities through the Ministry of Finance.

\section{The financial position of the major participants on the medicinal products market in Croatia from 2013 to 2017}

The strong upward trend in the manufacture of pharmaceutical preparations continues affecting the production of the entire industry. According to the data obtained from the Croatian Bureau of Statistics there are more than 30 active pharmaceutical companies in Croatia with the total headcount of around 5,00o workers, and the average gross salary of EUR I,9I0.00. The pharmaceutical industry has a 7\% share in the total export.

Although more than 30 companies operate in the Croatian pharmaceutical industry, the ten largest Croatian pharmaceutical manufacturers and distributors (wholesale pharmacies) 
generated more than 90\% of the entire sector revenue in 2017 and employed more than 90\% of workers. When it comes to revenue, the following manufacturers stand out: Pliva, Jadran galenski laboratorij (JGL) and Belupo.

Table 4 shows the growth of the total revenue and expenditure of the leading and profitable pharmaceutical manufacturers and wholesale pharmacies that generated the average profit of HRK 400 million in the considered period.

Table 4 The key performance indicators of the ten selected pharmaceutical companies in Groatia from 2013 to 2017 (HRK billion)

\begin{tabular}{|c|c|c|c|c|c|c|}
\hline & 2013 & 2014 & 2015 & 2016 & 2017 & \multirow{13}{*}{$\begin{array}{l}\text { Source: } \\
\text { calculation by the } \\
\text { author based on the } \\
\text { financial statements } \\
\text { of the selected } \\
\text { companies for the } \\
\text { period 20I3-20I7 }\end{array}$} \\
\hline Operating revenue & 6.78 & 7.05 & 7.19 & 8.05 & 8.OI & \\
\hline Financial revenue & O.I2 & 0.26 & 0.25 & 0.27 & 0.34 & \\
\hline Total revenue & $6.9 \mathrm{I}$ & 7.31 & 7.44 & 8.32 & 8.35 & \\
\hline Operating expenditure & $6.2 \mathrm{I}$ & 6.17 & 6.63 & 7.03 & 7.33 & \\
\hline Financial expenditure & 0.34 & 0.49 & 0.62 & 0.38 & 0.23 & \\
\hline Total expenditure & 6.55 & 6.66 & 7.25 & $7.4 \mathrm{I}$ & 7.56 & \\
\hline Net profit & 0.46 & 0.66 & 0.30 & 0.74 & 0.64 & \\
\hline Investment & 0.60 & 0.68 & 0.48 & O.9I & $0.5 \mathrm{I}$ & \\
\hline Import in the observed period & 2.5 & 2.6 & 3.0 & 3.7 & 4.0 & \\
\hline Revenues from selling abroad & 3.2 & 3.7 & 3.8 & 3.5 & 3.9 & \\
\hline $\begin{array}{r}\text { Selling abroad as a percentage } \\
\text { of the overall revenue }\end{array}$ & 46 & $5 \mathrm{I}$ & 52 & 42 & 47 & \\
\hline Total & 4,154 & 4,250 & 4,346 & 4,393 & 4,465 & \\
\hline
\end{tabular}

Pharmaceutical companies make a stable sector with a continuous revenue growth (total of around $20 \%$ in the considered period). The sector is profitable, and the revenue growth coincides with the growth of investment into new, long-term assets. Imports have substantially increased, and the revenue from selling abroad amounted to almost 50\% of the overall sales revenue. Pliva generated more than half of the revenue of all companies considered in total followed by Phoenix-farmacija wholesale pharmacy, and the manufacturers Jadran galenski laboratorij and Belupo. It is interesting that Imunološki zavod has $9 \%$ share in the total asset value of the ten largest pharmaceutical companies, but generates the insignificant o.II\% revenue. This is a result of week business operations and outstanding issues regarding the ownership structure. 


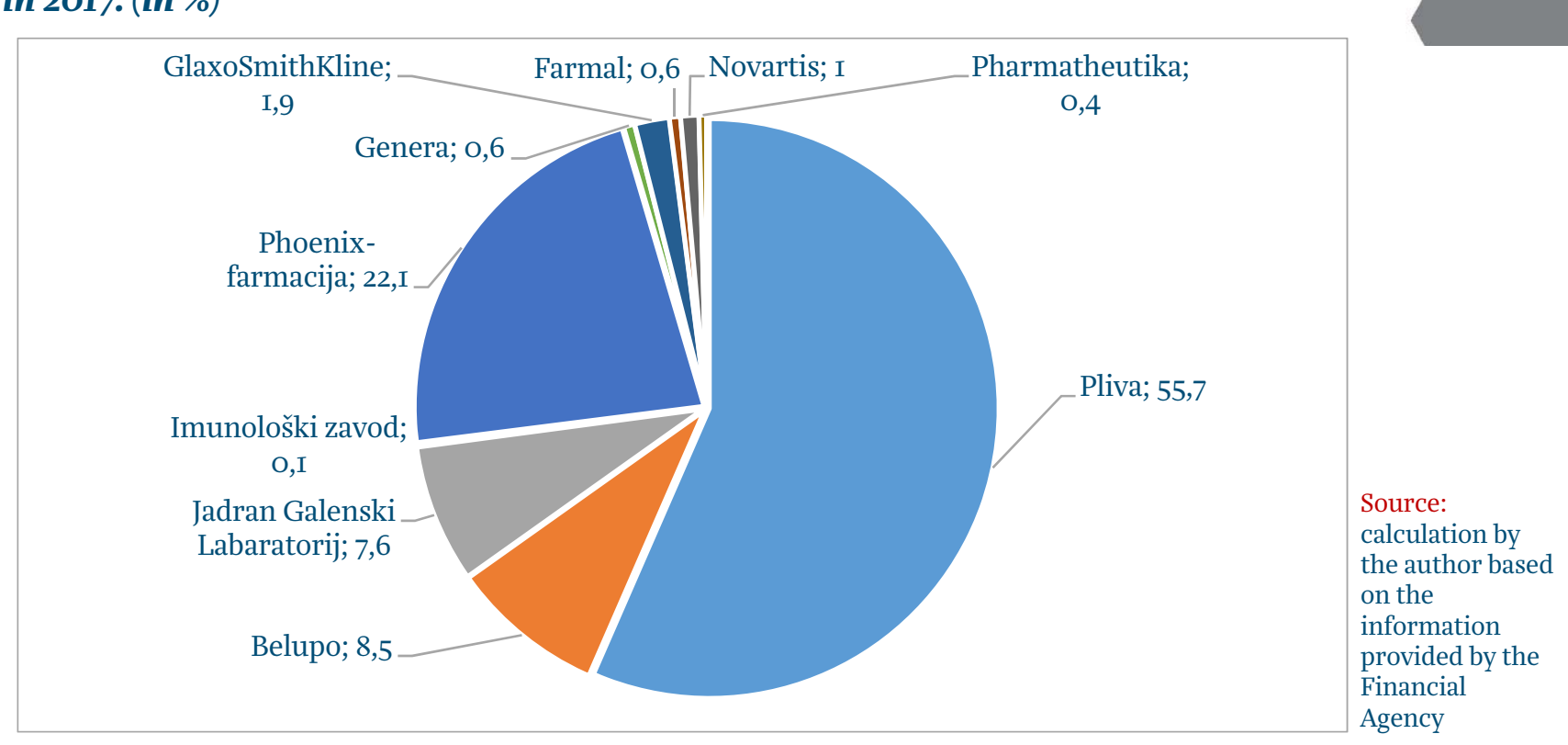

Assets and liabilities and financial results of the pharmaceutical companies from 2013 to 2017

Assets of the considered pharmaceutical companies amount to around HRK II billion, but by the end of the observed period, the long-term assets reduced by about $15 \%$, mostly as a result of a decrease in financial assets. By the end of the respective period, the short-term assets also reduced, mostly due to reduction in customer demand and granted short-term loans and deposits, but the capital and reserves grew as a result of profit brought forward from previous years and growth in equity share. The overall sector is deleveraging - long-term liabilities dropped by $69 \%$ in 2016.

Pliva recorded 61.3\% share in total assets in 20I7. Therefore, all changes in the balance sheet structure and changes on the pharmaceutical market in general, depend highly on changes in business operations of Pliva. According to their share in the total assets of ten largest pharmaceutical companies, the biggest manufacturers of medicinal products after Pliva are: Belupo (I4\%), Jadran galenski laboratorij (9\%) and Imunološki zavod (9\%).

Table 5 Balance sheet of ten largest pharmaceutical companies in Groatia from 2013 to 2017 (HRK billion)

\begin{tabular}{|c|c|c|c|c|c|c|}
\hline & 2013 & 2014 & 2015 & 2016 & 2017 & \\
\hline Long-term assets & 5.98 & 6.43 & 6.95 & 5.88 & 5.86 & \\
\hline Short-term assets & 5.88 & 6.35 & 4.43 & 5.04 & 5.13 & \\
\hline Total Assets & II.86 & I2.78 & II.38 & IO.93 & IO.99 & \\
\hline Capital and reserves & 5.70 & 5.63 & $5 . \mathrm{OI}$ & 5.76 & 5.88 & \\
\hline Long-term liabilities & 3.36 & 4.38 & 3.72 & I.I7 & I.O4 & \\
\hline Short-term liabilities & 2.79 & 2.77 & 2.65 & 4.00 & 4.07 & \\
\hline Total Liabilities & II.86 & 12.78 & II.38 & IO.93 & IO.99 & $\begin{array}{l}\text { Financial } \\
\text { Agency (2OI8) }\end{array}$ \\
\hline
\end{tabular}




\section{Chart 5 Share of individual pharmaceutical manufacturers in total assets of the leading pharmaceutical companies in Groatia in 2017}

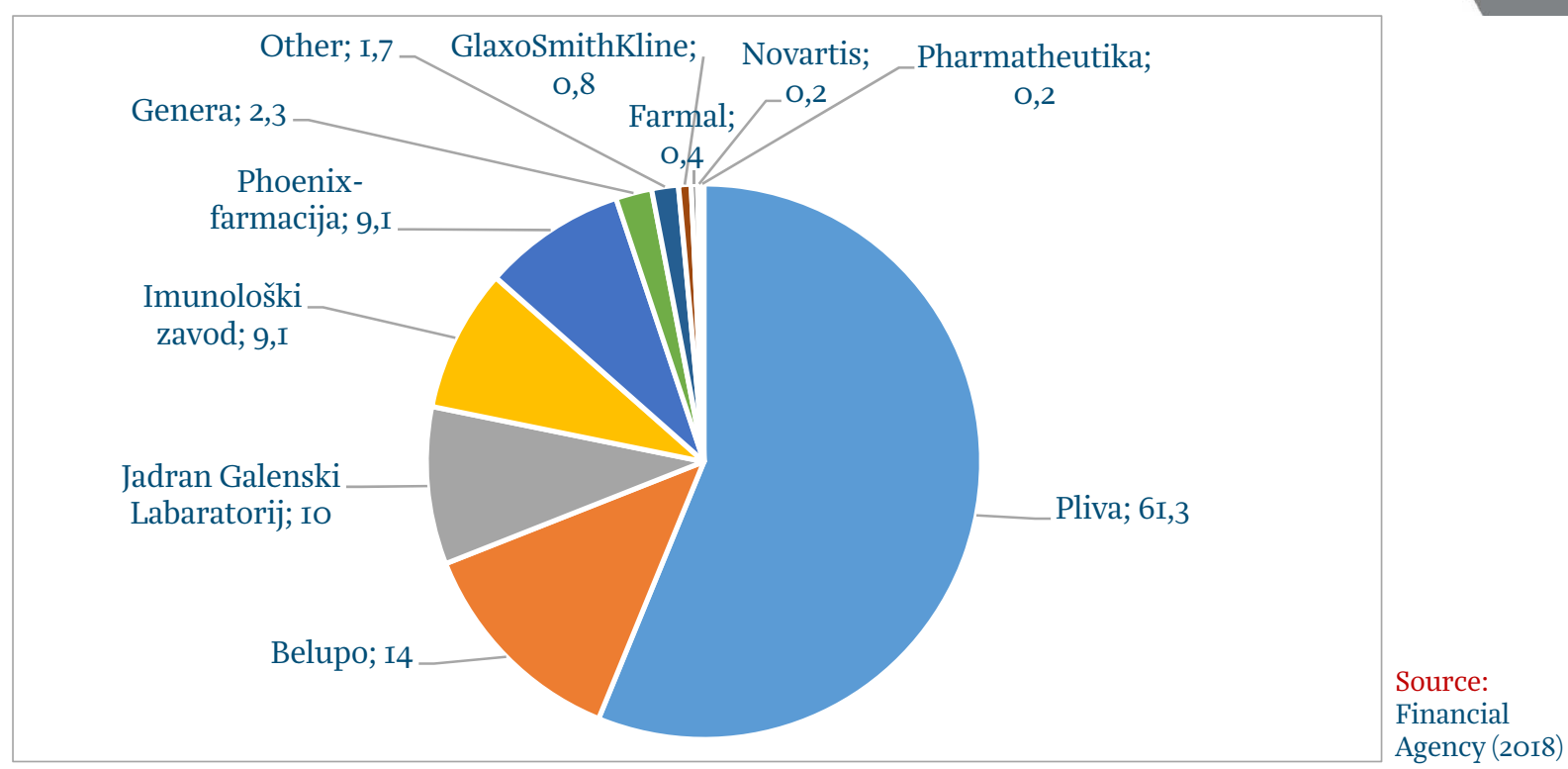

The analysis of the selected performance indicators of the pharmaceutical manufacturers in Croatia from 2013 to 2017

The suppliers of products and services, as well as creditors, are interested in the assessment of abilities of a company to settle the short-term liabilities (liabilities becoming due within a year), thus the liquidity indicators are used for the assessment of ability to pay short-term loans. The current ratio of the leading pharmaceutical companies (six manufacturers and four wholesale pharmacies) in 2017 amounted to from the alarming 0.26 (Imunološki zavod) to rather good 4.42 (Jadran galenski laboratorij). The higher value of the current ratio provides for a better debtor's position. In this example, however, the liquidity analysis was hampered by the fact that the most profitable pharmaceutical companies had problems with a high share of claims, so their actual liquidity level here is still somewhat lower. This is also supported by the fact that the share of claims in the short-term assets of JGL company ranged from 60\% to almost $80 \%$ in the period from 2013 to 2017.

The financial stability ratio is a ratio of long-term assets and long-term sources of finance (equity and long-term liabilities). If the indicator is below I, this means that a part of the shortterm liabilities is financed from long-term sources of finance, which reflects prudent financial management. In 2017, GlaxoSmithKline recorded the lowest financial stability ratio of 0.04, whereas the highest financial stability ratio of 7.85 was recorded by FARMAL. It must be emphasised that the ratio above I implies a lack of the net working capital, and a high debt to equity ratio, and a negative equity value as well, additionally confirms problems in business operations of FRAMAL (total liabilities of FARMAL were 2.5 times higher than total assets). 
Table 6 Financial indicators of the leading pharmaceutical companies in Groatia in 2017

\begin{tabular}{|c|c|c|c|c|c|c|c|c|c|}
\hline Company & CLR & FSR & DR & DTER & CP & NPM & ROA & ROE & \\
\hline BELUPO & 2.52 & 0.79 & 0.40 & 0.66 & I32.82 & 0.09 & 0.04 & 0.07 & \\
\hline FARMAL & 0.53 & 7.85 & 2.54 & -1.65 & IIO.76 & -0.18 & -0.18 & 0.12 & \\
\hline Genera & 2.20 & 0.60 & 0.60 & I.53 & 2I4.IO & -0.04 & -0.03 & -0.06 & \\
\hline GSK & 3.85 & 0.04 & 0.25 & 0.34 & 202.44 & 0.03 & 0.06 & 0.08 & \\
\hline Imunološki zavod & 0.26 & I. 77 & 0.62 & I.65 & 332.86 & -0.37 & -0.02 & -0.05 & \\
\hline JGL & 4.42 & $0.6 \mathrm{I}$ & 0.50 & I.OO & 246.40 & O.II & 0.07 & 0.13 & \\
\hline Novartis & I.2I & 0.43 & 0.73 & 2.73 & 71.02 & O.OI & 0.04 & O.I4 & \\
\hline PHARMATHEKA & 0.82 & $\mathrm{I} .2 \mathrm{O}$ & 0.72 & 2.55 & 23.95 & 0.06 & O.IO & 0.37 & \multirow{3}{*}{$\begin{array}{l}\text { Source: } \\
\text { Financial Agency } \\
\text { (2018) }\end{array}$} \\
\hline PHOENIX & $\mathrm{I} .27$ & 0.29 & 0.73 & 2.65 & 140.92 & 0.00 & 0.00 & 0.00 & \\
\hline PLIVA & I.O5 & 0.96 & $0.4 \mathrm{I}$ & 0.69 & 127.39 & O.II & 0.08 & 0.13 & \\
\hline
\end{tabular}

Note: CLR - Current Liquidity Ratio, FSR - Financial Stability Ratio, DR - Debt Ratio, DTER - Debt to Equity Ratio, CPcollection period, NPM - Net Profit Margin, ROA - Return on Assets, ROE - Return On Equity

The considered companies are mostly profitable, and net profit margin in 2017 amounted from negative $-37 \%$ (Imunološki zavod) to positive II\% (JGL and Pliva). The net profit margin is the most precise performance indicator and shows the percentage of revenue that converts into the profit. The considered companies are mostly profitable - except FARMAL, Genera and Imunološki zavod. The return on assets amounts to up to IO\%, and the return on equity up to $37 \%$ (the maximum values of both indicators refer to PHARMATHEKA).

\section{Conclusion}

- The steadily increasing consumption of medicinal products has been systematically and comprehensively tracked in Croatia since 2004 and it reached the value of HRK 6 billion in 2017.

- The ten largest Croatian pharmaceutical manufacturers and distributors (wholesale pharmacies) generated more than 90\% of the total sector revenue in 2017 and employed more than $90 \%$ of the total headcount in the sector.

- The pharmaceutical companies represent a stable sector with a continuous revenue growth (around 20\% in total in the considered four-year period). When it comes to the revenue generated, the following manufacturers stand out: Pliva, Jadran Galneski Laboratorij (JGL) and Belupo.

- The domestic manufacturers of medicinal products gradually lose their market share, which is more a result of a price reduction of medicinal products than of reduced sales.

- Pliva generated more than a half of the total revenue of the considered companies, it is followed by Phoenix-farmacija wholesale pharmacy, and the manufacturers Jadran galenski laboratorij and Belupo.

- The asset value of the ten leading pharmaceutical companies amounts to around HRK II billion and their liabilities amount to around HRK 5 billion in total.

- Imunološki zavod has $9 \%$ share in the total asset value of the ten largest pharmaceutical companies, but generated the insignificant 0.II\% revenue. This is a consequence of week business operations and outstanding issues regarding the ownership structure. 
- In the considered four years, the total spending on medicinal products amounted to HRK 27.4 billion, and the revenue generated from the sales of pharmaceutical companies amounted to HRK 35.7 billion. Therefore, the companies generated total surplus of HRK 8.3 billion.

- The sector is profitable, and the revenue growth coincides with the growth of investment into new, long-term assets. A substantial increase of import is evident, and the revenue from selling abroad amounted to almost 50\% of the overall sales.

- The most liquid pharmaceutical companies cope with high share of claims (mostly generated by public hospitals), which is the reason for their lower actual liquidity.

- The considered companies are mostly profitable - except FARMAL, Genera and Imunološki zavod.

- The return on assets amounts to up to I0\%, and the return on equity to $37 \%$ (the maximum values of both indicators refer to PHARMATHEKA).

- The financial stability ratio reveals problems in business operations of FRAMAL, which is additionally confirmed by a high debt to equity ratio (total liabilities of FARMAL are 2.5 times higher than total assets), and negative equity value.

- The medicinal products market is largely affected by the demand of healthcare institutions (primarily public hospitals) that are also the main source of outstanding government liabilities.

- The public hospitals are not successful in meeting their liabilities towards suppliers (wholesale pharmacies and pharmaceutical companies) throughout the year. The annual cost of outstanding invoices for medicinal products quite often exceeds HRK I billion. The Government borrows money for lump-sum settlements of hospitals' liabilities towards suppliers, but such liabilities accumulate again within a two-year period and reach the amount of HRK I billion.

\section{Recommendations to the Government:}

- Perform the analysis of business operations of companies in the segment of wholesale and retail (especially pharmacies) of medicinal products, compare the business operations of domestic and foreign pharmaceutical companies and perform a detailed market analysis of expensive medicinal products.

- The public institutions (hospitals) must operate more rationally in order to reduce the annual outstanding liabilities and bring them under HRK 300 million, and the Government needs to evaluate their performance in accordance with the criteria of cost control and prevention of new outstanding liabilities towards suppliers. 


\section{References}

I. Barbić, T., 20I7. Sektorska analiza-Farmaceutska industrija. Zagreb: Ekonomski institut Zagreb.

2. Broz, T., 20I4. Potrošnja lijekova i specifičnost funkcioniranja tržišta lijekova u: M. Vehovec, ur. O zdravstuu iz ekonomske perspektive. Zagreb: Ekonomski institut, 22I-243.

3. DiMasi,J. A.,20I6. Innovation in the pharmaceutical industry: New estimates of R\&D costs. Journal of Health Economics, 47, 20-33.

4. Draganić, P. et al., 20I6. Potrošnja lijekova u Hrvatskoj 20IO.-20I4. godine. Zagreb: Agencija za lijekove i medicinske proizvode.

5. Draganić, P., Škribulja, M. and Oštarčević, S., 20I6. Potrošnja lijekova u Hrvatskoj 20I220I6. Zagreb: HALMED.

6. EFPIA, 20I7. The Pharmaceutical industry in figures. Brussels: European Federation of Pharmaceutical Industries and Associations.

7. Enright, S. and Dalton, M., 20I4. The impact of the patent cliff on Pharma-Chem output in Ireland. Journal of the Statistical and Social Inquiry Society of Ireland, 43(I4), 9I-II3.

8. European Commission, 2009. Competitiveness of the EU Market and Industry for Pharmaceuticals. Rotterdam: ECORYS Nederland BV.

9. Eurostat, 20I8. Population on I January.

IO. Financial Agency, 20I8. Javna objava financijskih izvješća svih trgovačkih društava u RH. Zagreb: Financial Agency.

II. Horvat, D. M. and Siketić, M., 20I7. Mikroekonomska analiza farmaceutskog tržišta u RH u vrijeme ekonomske krize. Zbornik radova Međimurskog veleučilišta u Čakovcu, 8(2), 26-36.

I2. HZZO, 20I8. Godišnja izvješća o poslovanju od 2OI2. do 2OI7. Zagreb: HZZO.

I3. Mamić Sačer, I. et al., 2017. Analiza financijskih izvještaja. Zagreb: Hrvatska zajednica računovođa i financijskih djelatnika.

I4. Ministarstvo zdravstva Republike Hrvatske, 20I2. Nacionalna strategija razvoja zdravstva 20I2.-2O2O. Zagreb: Ministarstvo zdravstva Republike Hrvatske.

I5. Ostojić, R., Bilas, V. and Franc, S., 20I3. Politika lijekova i ugradbenih materijala u zemljama Europske unije i Republici Hrvatskoj. Economy and Market Communication Review, 3(I), 22-4I.

I6. Ostojić, R., Bilas, V. and Franc, S., 20I5. Stanje i perspektive razvoja europskih zdravstvenih sustava. Zagreb: Notitia.

I7. Pogorilić, S., 20I6. Hrvatska među zemljama s najmanjom potrošnjom inovativnih lijekova. Pharmabiz, (24), 38-42.

I8. Pravilnik o mjerilima za određivanje cijena lijekova na veliko i o načinu izvješćivanja o cijenama na veliko, NN 83/I3, I2/I4, 69/I4, 2I/I5. Zagreb: Narodne novine.

19. Pravilnik o mjerilima za stavljanje lijekova na osnovnu i dopunsku listu lijekova HZZOa, NN 83/I3, I2/I4. Zagreb: Narodne novine.

20. Zakon o lijekovima i medicinskim proizvodima, NN I2I/O3, I77/I4. Zagreb: Narodne novine.

2I. Zakon o lijekovima, NN 76/I3, 90/I4. Zagreb: Narodne novine. 



\section{Fiscus}

Fiscus is an analytical serial publication of the Institute of Public Finance. It aims at analyzing current economic issues that affect the stability of public finances or are related to the production of goods and the provision of services of broader public interest. The topics concerned have not received adequate attention in the academic and professional community and relate to economic sectors in which the public interest is concerned, directly or indirectly. On scientific and professsional foundations, Fiscus seeks to empower and encourage public debate on the establishment and preservation of the stability of Croatian public finances and the economy in general by promoting transparent, prudent and responsible management. Therefore, the topics focus on the identification and quantification of potential risks that could threaten the stability of public finance, market development, the competitiveness of the Groatian economy and the economic position of the citizens.

The vision of Fiscus is to become a reliable source of sectoral analyses through the prism of interaction between the public and private sector.

The mission of Fiscus is to identify the key challenges faced by certain economic sectors and offer suggestions for the improvement and preservation of the long-term stability of the Croatian economy.

The main objectives are:

- to provide in-depth analysis of the financial operations of public sector institutions and those institutions that are in any way associated with the production of goods and the provision of services of a broader public interest;

- to improve understanding of the financial consequences of their operations and increase accountability;

- to provide objective information on their business operations to the broader professional public and to investors;

- to contribute to the removal of administrative barriers to the development of competetiveness and the market economy.

Publisher: Institute of Public Finance Zagreb, Smičiklasova 2I

Phone: (+385 I) 4886444 | fiscus@ijf.hr Editors: Anto Bajo and Marko Primorac www.ijf.hr/eng/fiscus 